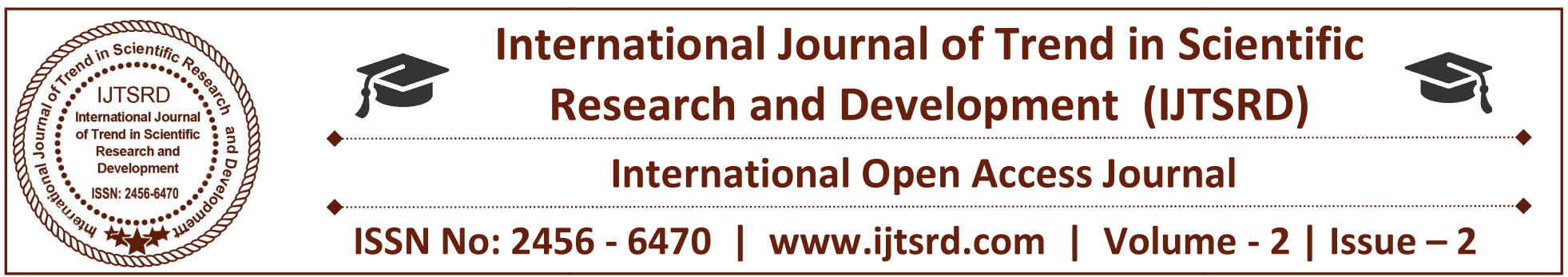

\title{
Effect of Confinement on Reinforce Concrete Short Rectangular Column
}

\author{
Khatri A. P \\ Assistant Professor, Department of Civil Engineering, \\ Bhivarabai Sawant College of Engineering and Research, Narhe, Pune, Maharashtra India
}

\section{ABSTRACT}

In this paper presents a comparative investigation based on various types of effective confining material, like (stapled stirrups, WWM, welded spot stirrups, ferrocement, FRP). The transverse reinforcement plays an important role in the ductility of the column. The preparedness for the formation of the plastic hinges in column, it requires confinement of concrete by transverse reinforcement.

To study the effectiveness of the Confinement reinforcement, its quantity, working out the optimum combination of the confinement reinforcement and also the load carrying capacity of the rectangular column. The study of rectangular column is significant as it is used mostly in the practical building construction. This project is high lighting the study of "study the different types of effective confining material on RC rectangular column" by improving the confining quality. It also adds the different properties of reinforced concrete column.

Keywords: $W W M, F R P$, Confinement

\section{INTRODUCTION}

Reinforced concrete column is used in all types of building constructions. Column transfers the load from beam and slab to foundation. Column support huge compressive forces in case of tall buildings. Column may suffer the damage due to over loading and natural disasters such as earthquakes and fires because of limited strength and ductility of concrete.
Failure of one or more columns may lead to the collapse of the structure.

The devastating earthquake at Bhuj Gujarat in 2001, shocked the entire nation. A large number of RCC buildings in the capital city of Ahemadabad, which is about $300 \mathrm{kms}$ from the epicenter were either badly damaged or collapsed. After the Bhuj mishap, the severity of the provisions in IS 13920-1993 was understood by the structural consultants. The percentage of secondary reinforcement in the column ranges from $0.25 \%$ to $0.35 \%$ of the main reinforcement.

The current equations for confinement reinforcement in IS 13920-1993 does not provide consistent level of safety against deformation and damage associated with flexural yielding during earthquakes. (Subramanian 2011). As per IS 19320-1993 the secondary reinforcement can be determine by using equation (1)

\subsection{Confined Concrete}

In recent years high rise reinforced concrete buildings more than 20 storey high have began to be constructed using strength concrete and transverse reinforcement with high strength steel. When columns with high strength concrete are subjected to severe seismic loading with high axial load, ductility demand for columns at yield zones may be satisfied only by providing the core concrete with intensive confinement achieved by using high strength 
transverse reinforcement. Thus, the importance of profound knowledge about the characteristics of confined concrete is increasing with increase of material strength used. Confinement of Concrete is to bind the concrete or to prevent the concrete from spalling. Due to this ductility is imparted to the column so as to resist the axial load, buckling of column, vibrations due to the Earthquake induced inertial forces, also formation of plastic hinges due to excess loading etc. If the area of the confined core is increased the correspondingly the ductility of the column increases. By the provision of the confinement reinforcement the area of the confined core increases. By the provision of the transverse reinforcement in the column in the form of spirals, cross ties etc., the area of confined core achieved is insufficient to dissipate the earthquake induced inertial forces. So it is necessary to provide extra reinforcement than the nominal.

$$
A_{s h}=0.18 \operatorname{Sh} \frac{f_{c k}}{f y}\left[\frac{A_{g}}{A_{k}}-1.0\right]
$$

Where,

$\mathrm{S}=$ Pitch of spiral or spacing of hoops,

$\mathrm{h}=$ longer dimension of rectangular confining hoop measured to its outer face. It shall not exceed 300 $\mathrm{mm}$.

$\mathrm{Ag}=$ Gross area of the column cross section.

$\mathrm{Ak}=$ Area of confine concrete core in the rectangular hoop measured to its outside dimensions.
The shortage of confinement offered by ties is the motivation for using materials such as Expanded Metal Mesh (EMM), Welded Wire Mesh (WMM) and Fiber Reinforced Polymer (FRP) to confine the concrete core (Ahmed 2015). Transverse reinforcement in columns is in the forms of hoops, cross-ties or spirals play an important role in safeguarding the columns, especially when they are subjected to strong Earthquakes. Hence an equation for the design of confinement reinforcement for ductile earthquake resistant rectangular and circular columns may be modified in the next revision of the code.

\section{Objectives:}

1) To check the effect of welded wire mesh as a confining reinforcement on rectangular column with different percentage of reinforcement and slenderness ratio.

2) To experimentally assess the performance of confined reinforcement along with conventional ties.

3) To compare the compressive strength of rectangular conventional column and confined column.

4) To study the failure pattern of confined column under compressive load.

Table 1 : Details of confinement

\begin{tabular}{|c|c|c|c|}
\hline Sr.no & $\begin{array}{l}\text { Types of } \\
\text { confinement }\end{array}$ & Research paper & Remark \\
\hline 1 & $\begin{array}{l}\text { Welded wire } \\
\text { mesh }\end{array}$ & $\begin{array}{l}\text { Improved confinement of reinforced } \\
\text { concrete column.(Ahmed M.El-Kholy) }\end{array}$ & $\begin{array}{l}\text { Increase ultimate load } \\
\text { capacity, better ductility, and } \\
\text { larger energy dissipation. }\end{array}$ \\
\hline 2 & $\begin{array}{l}\text { Welded spot } \\
\text { stirrups }\end{array}$ & $\begin{array}{l}\text { Ductility of RCC column with various } \\
\text { reinforcing arrangements.(D.Kato) }\end{array}$ & $\begin{array}{l}\text { increased the ultimate load } \\
\text { carrying capacity, }\end{array}$ \\
\hline 3 & Stapled stirrups & $\begin{array}{c}\text { Ductility of RCC confined with stapled } \\
\text { strips. } \\
\text { (M.F.Tahir) }\end{array}$ & $\begin{array}{l}\text { Ductility ratio is more ,load } \\
\text { carrying capacity is more. }\end{array}$ \\
\hline 4 & Ferro cement & $\begin{array}{l}\text { Behavior of RCC Column Confined with } \\
\quad \text { ferro cement.( Jatinder Malhotra) }\end{array}$ & $\begin{array}{l}\text { increased the ultimate load } \\
\text { carrying capacity, } \\
\text { increased the strength up to } \\
92 \%, \text { Lateral deflections are } \\
\text { significantly minimized. }\end{array}$ \\
\hline 5 & FRP & $\begin{array}{c}\text { Compressive behavior of concrete } \\
\text { confined by CFRP and transverse spiral } \\
\text { reinforcement.( Peng Yin) }\end{array}$ & $\begin{array}{l}\text { Increase ultimate loading } \\
\text { capacity }\end{array}$ \\
\hline
\end{tabular}




\section{Experimental Program}

Columns are failed in a plastic region in an excessive loading conditions like earthquake ect. It is necessary to strengthen or retrofit the column. To improve the strength, durability, reduce spalling of concrete by providing external confinement to the column. To achieve the required aim, the experimental program has been made. Column specimens were cast. These specimens are classified into different groups. This groups are based on different types of confining material to be used. There are three specimen were casted for each material. This experimental result gives various load-deflection graphs. Based on their load carrying capacity, deflection of column, cost ratio, durability, strength compare this confining material and gives a effective material to the confinement purposes which is, economical and effective.

UTM testing machine were used, a dial gauges are mounted on a four sides of specimen.

\section{CONCLUSION}

From the previous research papers result it is observed that confine column improves the compressive strength of column but from the various materials choosen for the test shows that welded wire mesh give the better results that other materials used for testing.

\section{REFERENCES}

1) Afifi, M.Z, Mohamed, H.M, Chaallal, O. and Benmokrane, B. (2015). "Confinement Model for Concrete Columns Internally Confined with Carbon FRP Spirals and Hoops." Journal of Structural Engineering, ASCE, 141(9), 04014219.

2) Dimitri, V. V. (2003). "Reliability of FiberReinforced Polymer-Confined Reinforced Concrete Columns." Journal of Structural Engineering, ASCE, 129 (8),1122-1130.

3) EI Ezz, A. A., Eldin, H. M., and Galal, K. (2015). "Influence of confinement reinforcement on the compression stress- strain of grouted reinforced concrete block masonry boundary elements." The Institution of Structural Engineers, Elsevier, 10 (2), 32-43.

4) EI-Kholy, A. $M$ and Dahish, H. A. (2016). "Improved confinement of reinforced concrete columns." Ain Shams Engineering Journal, 7(2), 717-728.

5) Elwood, K.J., and Eberhard, M.O. (2009). "Effective stiffness of reinforced concrete columns." ACI Structural Journal, 106 (4), 476484.

6) Fung-yuen, H.I., Lam Bo, E.S., and Wang, Y. (2013). "Monotonic Behavior of Reinforced Concrete Columns Confined with HighPerformance Ferro cement" Journal of Structural Engineering, ASCE, 139 (4), 574-583.

7) Subramanian, N. (2011). "Design of confinement reinforcement for RC columns" The Indian Concrete Journal.

8) Sakai, K., and Sheikh, S. A. (1989). "What Do We Know about Confinement in Reinforced Concrete Columns? (A Critical Review of Previous Work and Code Provisions)," ACI Structural Journal, 86 (2), 192-207.

9) Sharma, U., Bhargava, P., Kaushik, S.K., and Bhowmick, R. (2005). "Evaluation of confinement reinforcement requirements of IS 13920:1993 for RC columns." The Indian concrete Journal, 3 (3), 51-59.

10) IS 13920:1993, Indian standards code of practice for Ductile detailing of reinforced concrete structures subjected to seismic forces, Bureau of Indian Standards, New Delhi, India.

11) ACI 318:2008, Building Code Requirements for Structural Concrete, American Concrete 